

Original Research Article

https://doi.org/10.20546/ijcmas.2017.607.140

\title{
A Micro Economic analysis of production of banana in Kurnool district of Andhra Pradesh, India
}

\author{
M. Rama Krishna ${ }^{1}$, K.N. Ravi Kumar ${ }^{2}$ and I. Bhavani Devi ${ }^{1}$ \\ ${ }^{1}$ Deparment of Agricultural Economics, S V Agricultural College, Tirupathi, A.P., India \\ ${ }^{2}$ Deparment of Agricultural Economics, Agricultural College, Mahanandi, 518502, A.P., India \\ *Corresponding author
}

\section{A B S T R A C T}

Keywords

Banana, Costs and returns, Marginal farmers, Small farmers and other farmers.

Article Info

Accepted:

17 June 2017

Available Online:

10 July 2017
Banana (Musa paradisiaca $\mathrm{L}$ ) is the fourth largest fruit crop cultivated in the world. India is largest producer of banana in the world producing 28.45 million tonnes from an area of 0.796 million ha with a productivity of 35.7 $\mathrm{MT} \mathrm{ha}^{-1}$. This paper presents the costs and returns structure of banana in Kurnool district of Andhra Pradesh. A sample of 120 farmers was randomly selected. The farmers were stratified into Marginal ( $<1 \mathrm{ha})$, Small (1-2 ha) and other ( $>2 \mathrm{ha}$ ) categories on the basis of their size of operational holding. The total cost of cultivation of banana per hectare was Rs. 3, 27, 531.06, Rs. 3, 13, 337.47, Rs. 2, 47, 989.47 and Rs. 3, 21, 323.07 on marginal, small, other and pooled farms respectively. The gross returns were Rs. 4.47, 592. 71, Rs. 4, 78, 306.13 and Rs. 4, 91, 516.58 and 4, 79, 795.94 on marginal, small, other and pooled farms respectively indicated direct relationship with the farm size.

\section{Introduction}

India has been bestowed with wide range of climate and physio-geographical conditions and as such is most suitable for growing various kinds of horticultural crops such as fruits, vegetables, flowers, nuts, spices and plantation crops. This diverse climate ensures production of all varieties of fresh fruits in the country. As per National Horticulture Data base, during 2011-12 India produced 76.424 million metric tonnes of fruits in an area of 6.704 million ha. Among fruits, the country ranks first in production of bananas $(27.85 \%)$, papayas $(35.31 \%)$ and mangoes (including mangos teens and guavas) (39.04\%).
Banana (Musa paradisiaca L) is the fourth largest fruit crop cultivated in the world. It is grown in more than 130 countries across the world with an area of 5.14 million ha producing 105.32 million tonnes of banana in the year 2011-12 (www.fao.org). India is largest producer of banana in the world producing 28.45 million tonnes from an area of 0.796 million ha with a productivity of 35.7 MT ha ${ }^{-1}$ and accounted for 15.48 and 27.01 per cent of the world's area and production respectively (www.fao.org). Andhra Pradesh stood fourth in banana production with 3242.80 thousand metric tons 
during 2012-13 occupying an area of 92.65 thousand ha. It is largely grown in the districts of East Godavari, Kadapa, Ananthapur, West Godavari, Viziayanagaram, Kurnool and Guntur. Kurnool stood sixth place in the state in banana cultivation with an area of 5,756 ha and production of 201.78 thousand metric tons next to East Godavari, Kadapa, Ananthapur, West Godavari and Viziayanagaram during 2012-13. However, in recent years, banana farmers are facing several problems in production and marketing of the produce. Therefore, an attempt is made in the present study to examine the performance of production of banana in Kurnool district of Andhra Pradesh.

\section{Materials and Methods}

\section{Study regions and data}

Kurnool district in Andhra Pradesh was purposively selected for the study, as the district harbours significant area of 3373 hectares under banana cultivation in the year 2013-14. All the mandals in the Kurnool district along with their banana cultivated area was listed out in descending order and top two mandals were selected viz., Mahanandi and Nandyal. Similarly, two villages were selected from each mandal. At village level, the banana cultivating farmers will be categorized according to their land holding size i.e., Marginal (<1 ha), Small (1-2 ha) and other farmers $(>2$ ha). From these three different categories, a total of 120 farmers were selected at random, representing 40 farmers from each category. Thus a sample of 120 farmers was used for the analysis.

\section{Costs concepts}

Enterprise budgeting was worked out to analyze cost and returns of banana enterprise. For the computed costs, as suggested by the Commission for Agricultural Costs and Prices
(CACP) Cost concepts were worked out. The cost concepts viz., Cost A1, Cost A2, Cost B1, Cost B2, Cost C1, Cost C2 and Cost C3 were used in the present study and these are derived as follows:

\section{Cost A1}

This cost includes value of purchased material inputs (seed, insecticides and pesticides, manure, fertilizer) hired human labour, animal labour (owned and hired) machinery labour (owned and hired), depreciation on farm implements and farm buildings, irrigation charges, land revenue, cesses and other taxes and interest on working capital.

\section{Cost A2}

Cost $\mathrm{A} 1+$ rent paid for leased in land.

Cost A2 + FL

Cost A1 + imputed value of family labour

\section{Cost B1}

Cost A1 + interest value of owned capital assets (excluding land)

\section{Cost B2}

Cost B1 + rental value of owned land (net of land revenue) and rent paid for leased-in land

\section{Cost C1}

Cost B1 + imputed value of family labour.

\section{Cost C2}

Cost B2 + imputed value of family labour.

\section{Cost C3}

Cost $\mathrm{C} 2+10 \%$ of Cost C2 (on account of managerial functions performed by the farmer) 


\section{Farm efficiency measures}

Farm business income $=$ Gross income - Cost A1

Owned farm business income $=$ Gross income - Cost A2

Family labour income $=$ Gross income - Cost B2

Net income $=$ Gross income - Cost $\mathrm{C} 3$

\section{Results and Discussion}

\section{Cost of cultivation of banana}

The profitability of any enterprise depends upon costs and returns. Generally, costs in any economic study are discussed under two heads viz., operational costs and fixed costs.

In general, operational costs alone are reckoned as the cost of cultivation by the farmers and profit and loss are worked out ignoring the overhead costs. But, in economic analysis of any business enterprise, the fixed costs are also taken into account to arrive at total costs and compute net profits.

The operational costs of banana farmers include costs on suckers, land preparation, digging ridges and furrows, planting, manures and fertilizers, desuckering, earthing up, weeding, irrigation, plant protection, watch and ward, harvesting and interest on working capital.

The fixed costs include the land revenue, depreciation charges, rental value of owned land and interest on fixed capital. The particulars of cost of cultivation of banana and share of different operational costs and total fixed costs per hectare for marginal, small, other and pooled farmers are presented through table 1.
The TCOC of banana was worked out to be Rs. 3, 21, 323.07 per hectare for pooled farmers. The average TCOC decreased with the increase in the size of the holdings from Rs. 3, 27, 531.06 on marginal farms, Rs. 3, 13, 337.47 on small farms to Rs. 2, 47, 989.47 on other farms indicating inverse relationship with the size of the holding. It was found that the operational costs accounted for a major share in the TCOC on all categories of farms.

The total operational costs ranged from Rs. 2, $56,640.62(78.36 \%)$ on marginal farms, Rs. $2,19,315.81(69.99 \%)$ on small farms to Rs $1,78,339.04(71.91 \%)$ on other farms, with an overall average of Rs 2, 25, 286.45 $(70.11 \%)$ on pooled farms.

It is evident from table 1 that, the cost of manures and fertilizers is the major cost component among operational costs with an amount of Rs. 97,400.40 accounting for 30.31 per cent of TCOC on pooled farms. The same was Rs. 1, 28, 732.00 on marginal farms, Rs. $1,00,586.14$ on small farms and Rs. $78,735.74$ on other farms accounting for $39.30,32.10$ and 31.75 per cents of their respective TCOC.

The next important operational cost was for digging ridges and furrows with an amount of Rs. $22,451.72$ on pooled farms. The same was Rs. $22,398.90$ (6.82\%) on marginal farms, Rs. $18,168.57(4.43 \%)$ on small farms and Rs. $8970.13(3.02 \%)$ on other farms. The other items of expenditure in the order of importance were suckers $(4.58 \%)$, land preparation (4.56\%), earthing up (4.33\%), watch and ward $(4.22 \%)$, weeding $(3.77 \%)$, harvesting (3.76\%), interest on working capital (1.96\%), desuckering (1.81\%), irrigation $(1.31 \%)$, planting $(1.19 \%)$ and plant protection $(0.92 \%)$ for pooled farms. More or less same trend was followed across all the size groups. 
Fixed costs per hectare were estimated at Rs. 70,890.44, Rs. 94,021.66, Rs. 69,650.44 and Rs. 96,036.62 accounting for 21.64, 30.01, 28.09 and 29.89 per cents of TCOC on marginal, small, other and pooled farms respectively as shown in table 1 .

The rental value of owned land was the major cost item among the fixed costs which accounted for 13.82, 14.43, 18.15 and 14.07 per cents on marginal, small, other and pooled farms.

Depreciation and interest on fixed capital were other fixed cost items accounting for 9.69 and 5.98 per cents respectively on pooled farms.

The overall analysis of TCOC of banana enterprise revealed that, the marginal farms incurred higher costs than small farms and other farms.

This was mainly because of intensive use of manures and fertilizers by the marginal farms compared to small and other farmers.

\section{Cost concepts in banana production}

The cost concepts were worked out as suggested by CACP. The cost concepts were Cost A1, Cost A2, Cost A2+FL, Cost B1, Cost $\mathrm{B} 2$, Cost $\mathrm{C} 1$, Cost $\mathrm{C} 2$ and Cost C3.

Of all the cost concepts, Cost C2 is the most comprehensive cost as it covers both operational costs and fixed costs. The TCOC of banana according to cost concepts was worked out and presented in table 2 .

It is clear that, there was no leasing activity among the selected farmers and hence cost $A_{1}$ and cost $\mathrm{A}_{2}$ were same. On an average, the TCOC (Cost C2) of banana per hectare was Rs. 3,21,323.07 on pooled farms. It was highest on marginal farms (Rs. 3,27,531.06) as compared to small farms (Rs. 3,13,337.47) and other farms (Rs. 2,47,989.47) indicating inverse relationship with farm size. The same trend was evident in the case of CostA1/A2, Cost A2+FL, Cost B1, Cost B2, Cost C1 and Cost C3.

\section{Output and returns from banana production}

From table 3 , it is clear that, the other farms recorded a yield of 2,223.45 bunches of banana compared to small farms $(2,192.92)$ and marginal farms $(2,142.82)$ per hectare. The same was 2,200.65 bunches on pooled farms.

More yields on other farms may be ascribed to the optimum use of inputs and input services in the cultivation of banana.

The gross returns obtained by marginal, small, other and pooled farms were Rs. 4,47,592.71, Rs. 4,78,306.13, Rs. 4,91,516.58 and Rs. 4,79,795.94 respectively.

The net returns obtained by marginal, small, other and pooled farms were Rs. 1,20,061.65, Rs. 1,64,968.66, Rs. 2,43,527.10 and Rs. $1,58,472.87$ respectively.

Thus the gross and net returns from banana enterprise were higher on other farms compared to small and marginal farms and accordingly rate of return per rupee spent was higher on other farms (0.98) followed by small (0.53) and marginal (0.37). At pooled level, the rate of return was 0.49 . Thus, the rate of return increases with increase in farm size and in terms of cost, the cost of production decreases with increase in farm size as shown through table 3 under economies of large scale production. 
Table.1 Cost of cultivation of banana-size-wise and component-wise

\begin{tabular}{|c|c|c|c|c|c|}
\hline S.No & Item & Marginal & Small & Others & Pooled \\
\hline I. & Operational Costs & & & & \\
\hline 1 & Suckers & $\begin{array}{l}14928.88 \\
(4.56)\end{array}$ & $\begin{array}{c}15388.74 \\
(4.91)\end{array}$ & $\begin{array}{c}14324.83 \\
(5.78)\end{array}$ & $\begin{array}{c}14719.40 \\
(4.58)\end{array}$ \\
\hline 2 & Land preparation & $\begin{array}{c}3788.96 \\
(1.16)\end{array}$ & $\begin{array}{c}7586.49 \\
(2.42)\end{array}$ & $\begin{array}{c}11440.58 \\
(4.61)\end{array}$ & $\begin{array}{c}15946.19 \\
(4.56)\end{array}$ \\
\hline 3 & $\begin{array}{l}\text { Digging ridges and } \\
\text { furrows }\end{array}$ & $\begin{array}{c}5874.38 \\
(1.79)\end{array}$ & $\begin{array}{c}10934.38 \\
(3.49)\end{array}$ & $\begin{array}{c}15279.25 \\
(6.16)\end{array}$ & $\begin{array}{c}22451.72 \\
(6.99)\end{array}$ \\
\hline 4 & Planting & $\begin{array}{c}3967.19 \\
(1.21)\end{array}$ & $\begin{array}{c}4123.64 \\
(1.32)\end{array}$ & $\begin{array}{c}3646.94 \\
(1.47)\end{array}$ & $\begin{array}{c}3832.13 \\
(1.19)\end{array}$ \\
\hline 5 & Manures and fertilizers & $\begin{array}{c}128732.00 \\
(39.30)\end{array}$ & $\begin{array}{c}100586.14 \\
(32.10)\end{array}$ & $\begin{array}{c}78735.74 \\
(31.75)\end{array}$ & $\begin{array}{c}97400.40 \\
(30.31)\end{array}$ \\
\hline 6 & Desuckering & $\begin{array}{c}6535.21 \\
(2.00)\end{array}$ & $\begin{array}{l}7279.57 \\
(2.32)\end{array}$ & $\begin{array}{c}4870.52 \\
(1.96)\end{array}$ & $\begin{array}{c}5816.11 \\
(1.81)\end{array}$ \\
\hline 7 & Earthing up & $\begin{array}{l}22398.90 \\
(6.84)\end{array}$ & $\begin{array}{c}18168.57 \\
(5.80)\end{array}$ & $\begin{array}{c}8970.13 \\
(3.62)\end{array}$ & $\begin{array}{c}13927.43 \\
(4.33)\end{array}$ \\
\hline 8 & Weeding & $\begin{array}{c}14892.42 \\
(4.55)\end{array}$ & $\begin{array}{c}12419.02 \\
(3.96)\end{array}$ & $\begin{array}{c}10992.47 \\
(4.43)\end{array}$ & $\begin{array}{c}12113.74 \\
(3.77)\end{array}$ \\
\hline 9 & Irrigation & $\begin{array}{c}8233.10 \\
(2.51)\end{array}$ & $\begin{array}{c}7058.47 \\
(2.25)\end{array}$ & $\begin{array}{c}1589.21 \\
(0.64)\end{array}$ & $\begin{array}{c}4193.86 \\
(1.31)\end{array}$ \\
\hline 10 & Plant protection & $\begin{array}{c}2616.78 \\
(0.80)\end{array}$ & $\begin{array}{c}2549.71 \\
(0.81)\end{array}$ & $\begin{array}{c}2599.84 \\
(1.05)\end{array}$ & $\begin{array}{c}2965.61 \\
(0.92)\end{array}$ \\
\hline 11 & Harvesting & $\begin{array}{l}15191.13 \\
(4.64)\end{array}$ & $\begin{array}{l}13234.19 \\
(4.22)\end{array}$ & $\begin{array}{c}13415.40 \\
(5.41)\end{array}$ & $\begin{array}{c}12090.71 \\
(3.76)\end{array}$ \\
\hline 12 & Watch and ward & $\begin{array}{c}22321.59 \\
(6.82)\end{array}$ & $\begin{array}{c}13868.15 \\
(4.43)\end{array}$ & $\begin{array}{c}7498.60 \\
(3.02)\end{array}$ & $\begin{array}{c}13543.82 \\
(4.22)\end{array}$ \\
\hline 13 & Interest on working capital & $\begin{array}{c}7160.09 \\
(2.19)\end{array}$ & $\begin{array}{c}6118.76 \\
(1.95)\end{array}$ & $\begin{array}{c}4975.53 \\
(2.01)\end{array}$ & $\begin{array}{c}6285.33 \\
(1.96)\end{array}$ \\
\hline & Total Operational Costs & $\begin{array}{c}256640.62 \\
(78.36)\end{array}$ & $\begin{array}{c}219315.81 \\
(69.99)\end{array}$ & $\begin{array}{c}178339.04 \\
(71.91)\end{array}$ & $\begin{array}{c}225286.45 \\
(70.11)\end{array}$ \\
\hline II. & Fixed Costs & & & & \\
\hline 1 & Land revenue & $\begin{array}{c}494.00 \\
(0.15)\end{array}$ & $\begin{array}{c}494.00 \\
(0.16)\end{array}$ & $\begin{array}{c}494.00 \\
(0.20)\end{array}$ & $\begin{array}{c}494.00 \\
(0.15)\end{array}$ \\
\hline 2 & Depreciation & $\begin{array}{c}14295.10 \\
(4.36)\end{array}$ & $\begin{array}{c}31822.08 \\
(10.16) \\
\end{array}$ & $\begin{array}{c}14231.29 \\
(5.74) \\
\end{array}$ & $\begin{array}{c}31125.77 \\
(9.69) \\
\end{array}$ \\
\hline 3 & $\begin{array}{l}\text { Rental value of owned or } \\
\text { leased in land }\end{array}$ & $\begin{array}{c}45249.03 \\
(13.82) \\
\end{array}$ & $\begin{array}{c}45227.70 \\
(14.43)\end{array}$ & $\begin{array}{c}45014.86 \\
(18.15)\end{array}$ & $\begin{array}{c}45197.57 \\
(14.07) \\
\end{array}$ \\
\hline \multirow[t]{3}{*}{4} & Interest on fixed capital & $\begin{array}{c}10852.32 \\
(3.31)\end{array}$ & $\begin{array}{c}16477.88 \\
(5.26) \\
\end{array}$ & $\begin{array}{c}9910.29 \\
(4.00) \\
\end{array}$ & $\begin{array}{c}19219.28 \\
(5.98) \\
\end{array}$ \\
\hline & Total fixed costs & $\begin{array}{c}70890.44 \\
(21.64)\end{array}$ & $\begin{array}{c}94021.66 \\
(30.01)\end{array}$ & $\begin{array}{c}69650.44 \\
(28.09)\end{array}$ & $\begin{array}{c}96036.62 \\
(29.89)\end{array}$ \\
\hline & Total costs & $\begin{array}{c}327531.06 \\
(100)\end{array}$ & $\begin{array}{c}313337.47 \\
\quad(100)\end{array}$ & $\begin{array}{l}247989.47 \\
\quad(100)\end{array}$ & $\begin{array}{l}321323.07 \\
\quad(100)\end{array}$ \\
\hline
\end{tabular}

Note: Figures in parentheses indicate percentages to the respective column totals 
Table. 2 Cost concepts in banana production (Rupees per hectare)

\begin{tabular}{|c|l|c|c|c|c|}
\hline S.No & \multicolumn{1}{|c|}{ Costs } & Marginal & Small & Others & Pooled \\
\hline \multirow{2}{*}{1} & Cost A1/A2 & $\begin{array}{c}254379.49 \\
(77.67)\end{array}$ & $\begin{array}{c}243545.60 \\
(77.73)\end{array}$ & $\begin{array}{c}187554.51 \\
(75.63)\end{array}$ & $\begin{array}{c}249618.47 \\
(77.68)\end{array}$ \\
\hline \multirow{2}{*}{2} & Cost A2+FL & $\begin{array}{c}271429.72 \\
(82.87)\end{array}$ & $\begin{array}{c}251631.89 \\
(80.31)\end{array}$ & $\begin{array}{c}193064.33 \\
(77.85)\end{array}$ & $\begin{array}{c}256906.22 \\
(79.95)\end{array}$ \\
\hline \multirow{2}{*}{3} & Cost B1 & $\begin{array}{c}265231.80 \\
(80.98)\end{array}$ & $\begin{array}{c}260023.48 \\
(82.99)\end{array}$ & $\begin{array}{c}197464.79 \\
(79.63)\end{array}$ & $\begin{array}{c}268837.74 \\
(83.67)\end{array}$ \\
\hline \multirow{2}{*}{4} & Cost B2 & $\begin{array}{c}310480.83 \\
(94.79)\end{array}$ & $\begin{array}{c}305251.18 \\
(97.42)\end{array}$ & $\begin{array}{c}242479.65 \\
(97.78)\end{array}$ & $\begin{array}{c}314035.31 \\
(97.73)\end{array}$ \\
\hline \multirow{2}{*}{5} & Cost C1 & $\begin{array}{c}282282.04 \\
(86.18)\end{array}$ & $\begin{array}{c}268109.77 \\
(85.57)\end{array}$ & $\begin{array}{c}202974.62 \\
(81.85)\end{array}$ & $\begin{array}{c}276125.50 \\
(85.93)\end{array}$ \\
\hline \multirow{2}{*}{6} & Cost C2 & $\begin{array}{c}327531.06 \\
(100)\end{array}$ & $\begin{array}{c}313337.47 \\
(100)\end{array}$ & $\begin{array}{c}247989.47 \\
(100)\end{array}$ & $\begin{array}{c}321323.07 \\
(100)\end{array}$ \\
\hline \multirow{2}{*}{7} & Cost C3 & $\begin{array}{c}360284.17 \\
(110)\end{array}$ & $\begin{array}{c}344671.22 \\
(110)\end{array}$ & $\begin{array}{c}272788.42 \\
(110)\end{array}$ & $\begin{array}{c}353455.38 \\
(110)\end{array}$ \\
\hline
\end{tabular}

Note: Figures in parentheses indicate percentages to the respective column totals

Table.3 Output and returns of banana farms per hectare

\begin{tabular}{|c|l|c|c|c|c|}
\hline S.No & \multicolumn{1}{|c|}{ Particulars } & Marginal & Small & Others & Pooled \\
\hline $\mathbf{1}$ & Yield (bunches) & $2,142.82$ & $2,192.92$ & $2,223.45$ & $2,200.65$ \\
\hline $\mathbf{2}$ & Gross returns (Rs) & $4,47,592.71$ & $4,78,306.13$ & $4,91,516.58$ & $4,79,795.94$ \\
\hline $\mathbf{3}$ & Total costs (Rs) & $3,27,531.06$ & $3,13,337.47$ & $2,47,989.47$ & $3,21,323.07$ \\
\hline $\mathbf{4}$ & Net returns (Rs) & $1,20,061.65$ & $1,64,968.66$ & $2,43,527.10$ & $1,58,472.87$ \\
\hline $\mathbf{5}$ & $\begin{array}{l}\text { Rate of returns (Net } \\
\text { turns/Total cost) }\end{array}$ & 0.37 & 0.53 & 0.98 & 0.49 \\
\hline $\mathbf{6}$ & $\begin{array}{l}\text { Cost of production } \\
\text { (Rs/bunch) }\end{array}$ & 152.85 & 142.89 & 111.53 & 146.01 \\
\hline
\end{tabular}

Table.4 Measures of farm income - banana production

\begin{tabular}{|c|l|c|c|c|c|}
\hline S.No. & Particulars & Marginal & Small & Others & Pooled \\
\hline 1. & Gross income & $4,47592.71$ & $4,78,306.13$ & $4,91,516.58$ & $4,79,795.94$ \\
\hline 2. & Net income & $87,308.54$ & $1,33,634.91$ & $2,18,728.15$ & $2,30,177.47$ \\
\hline 3. & $\begin{array}{l}\text { Farm business } \\
\text { income }\end{array}$ & $1,93,213.22$ & $2,34,760.53$ & $3,03,962.07$ & $1,65,760.63$ \\
\hline 4. & $\begin{array}{l}\text { Family labour } \\
\text { income }\end{array}$ & $1,37,111.88$ & $1,73,054.95$ & $2,49,036.93$ & $1,26,340.57$ \\
\hline 5. & $\begin{array}{l}\text { Farm } \\
\text { investment } \\
\text { income }\end{array}$ & $1,76,162.99$ & $2,26,674.24$ & $2,98,452.24$ & $2,22,889.72$ \\
\hline
\end{tabular}

Note: Figures in parentheses indicate percentages to the respective column totals 


\section{Measures of farm income}

An important aspect in farm business management and decision making relates to the manner in which available resources are allocated. A measuring rod is necessary to evaluate the optimal use of resources. To achieve this objective, various farm efficiency measures viz., gross income, net income, farm business income, family labour income, farm investment income and rate of returns were computed and presented in table 4 .

Gross income exhibited direct relationship with the farm size and it was of the order of Rs. 4,47,592.71, Rs. 4,78,306.13, Rs. 4,91,516.58 and Rs. 4,79,795.94 on marginal, small, other and pooled farms respectively. The gross income was more on other farms due to highest productivity compared to other categories of farmers. Though the gross income is a measure to assess the efficiency of the farm business, it alone does not help us to gauge the success of the farm business. Therefore, another measure namely net income, which represents surplus of gross income over total costs was estimated. The net income showed a direct relationship with the farm size. Other farms recorded a net income of Rs. 2,18,728.15 against Rs. 1,33,634.91 and Rs. 87,308.54 on small farms and marginal farms respectively. The same was Rs. 2,30,177.47 on pooled farms. This trend clearly revealed that, the other farms were more efficient in the utilization of resources and resource services in the production programme that contributed towards rise in production on one side and economizes cost on the other side.

Farm business income, which indicates returns on owned resources like land, labour and capital was also more on other farms (Rs. $3,03,962.07$ ) as compared to small farms (Rs. 2,34,760.53) and marginal farms (Rs. $1,93,213.22)$, which means the other farms were superior to small and marginal farms in productively using these resources.

Family labour income is another measure of farm efficiency representing the returns from farmer's own labour and family labour. Other farms derived family labour income amounting to Rs. 2,49,036.93, while it was Rs. $1,73,054.95$ and Rs. $1,37,111.88$ on small and marginal farms respectively. The same on pooled farms was Rs. 1,26,340.57.

Farm investment income, a measure of returns to fixed capital was Rs. 1,76,162.99, Rs.2,26,674.24, Rs. 2,98,452.24 and Rs. $2,22,889.72$ on marginal, small, other and pooled farms respectively.

In conclusion, the banana yield per hectare was 2,142.82 bunches on marginal farms, 2,192.92 bunches on small farms and 2,223.45 bunches on other farms. The gross returns were Rs. 4,47,592.71, Rs. 4,78,306.13 and Rs. 4,91,516.58 on the above farms respectively which showed a direct relationship with the size of the farm.

The cost of producing a bunch of banana (1 bunch $=150$ fingers) was more on marginal farms (Rs. 152.85 per bunch) than small farms (Rs. 142.89 per bunch) and other farms (Rs. 111.53 per bunch).

The farm business analysis in banana revealed that farm business income, family labour income, farm investment income, gross income and net income showed positive relationship with the size of holding.

The rate of returns per rupee of investment was Rs. 0.37, Rs. 0.53, Rs. 0.98 and Rs. 0.49 on marginal, small, other and pooled farms respectively, which showed that banana cultivation, is more profitable on other farms compared to small farms and marginal farms. 


\section{References}

Ahmedmukul, A.Z and Rahman, W. 2013. Production and Profitability of banana in Bangladesh-An economic analysis. International journal of Economics, Finance and Management Sciences. Vol-1 (3): 159-165.

Apparao, T., Raghuram, $\mathrm{P}$ and Sankararao, D.V. 1986. Cost and Returns in banana farms. Agricultural Banker. 9 (3): 6-8.

Gangal, S.M. 2002. Performance of banana plantation in North Karnataka -An economic analysis. Unpublished M.Sc. (Ag.) Thesis. University of Agricultural Sciences, Dharwad.

Hiremath, G.M. 1993. Economics of production and marketing of lime in Bijapur district, Karnataka. Unpublished M.Sc. (Ag.)Thesis.
University of Agricultural Sciences, Dharwad.

Jyothi, S.H and Suhasini, K. 2013. Economics of Tapioca cultivation in Jaggampeta mandal of East-Godavari district of Andhra Pradesh. Agricultural Situation in India. ' Vol LXX, pp: 9-14.

Kulapati, Hipparagi, Chinnappa, B., Nagaraj, H. I and Hipparagi, K. 1999. Identification of banana cultivar with high yield and profit for Bhadra Command. Mysore Journal of Agricultural Sciences. 33(3): 151-156.

Mali, B.K., Bhosle, S.S., Shendage, P.N and Kale, P.V. 2001. Economics of production and marketing of banana in Jalgaon district of Western Maharashtra. Indian Journal of Agriculture Marketing. 17 (1): 173-179.

\section{How to cite this article:}

Rama Krishna, M., K.N. Ravi Kumar and Bhavani Devi, I. 2017. A Micro Economic Analysis of Production of Banana in Kurnool District of Andhra Pradesh. Int.J.Curr.Microbiol.App.Sci. 6(7): 1152-1159. doi: https://doi.org/10.20546/ijcmas.2017.607.140 